\title{
ANALYSIS OF THE CORRELATION BETWEEN SAFETY MANAGEMENT AND MARINE INSPECTOR CONTROL WITH THE VOYAGE SAFETY OF MT. MARLIN 8
}

\author{
Arif Rahman ${ }^{1}$, Marthaleina $\mathbf{R S}^{2}$, Yuliantini ${ }^{3}$ \\ 1. STMT Trisakti, 2. STMT Trisakti, 3. STMT Trisakti \\ $\square$ corresponding author: ariflucky26@gmail.com,
}

\begin{abstract}
Someone who travels requires mandatory safety and comfort, Meanwhile, transported goods must remain intact and not diminish in quality when they arrive at the destination. The purpose of this research is to know the relationship between safety management and supervision of marine inspector with MT Marlin 8 sailing safety at PT. Patria Nusasegara 2017. The sample that the researchers used in this study, was obtained by sampling technique (nonprobability sampling) with saturated sampling from as many as $30 \mathrm{crew}$ of MT. Marlin 8 ship at PT. Patria Nusasegara. The result of the research showed that the safety inspector and the supervision of Marine inspector together have a positive and significant relation with the safety of MT. Marlin 8 Shipping. The calculation results showed that the strength of the relationship is indicated by the correlation coefficient as equal to 0,814 . It can be concluded that if the safety management and marine inspector are jointly improved then the safety of MT. Marlin 8 voyages will increase. Thus, the Ha3 research hypothesis is accepted, because $\mathrm{F}$ count $>\mathrm{F}$ table or $26,427>3,354$. So, H0 is rejected and Ha is accepted. It means that, in multiply situation, there is a significant positive relation between safety management and supervision marine inspector with safety of MT. Marlin 8.
\end{abstract}

Keywords: Safety Management, marine Inspector control, voyage safety of MT. Marlin 8

\section{Introduction}

The main causes of marine accidents in general are due to the excess transport factor of the transport power that is determined either by the freight transport or by the transportation of persons. It is not infrequently that shipping service users force themselves on board even though the ship is full. The transportation system is designed to facilitate the movement of human and the transportation service is designed especially for goods. Both are closely related to the safety of both people and goods. A person traveling requires mandatory safety and if it is possible, to obtain comfort. Mean while the goods transported must remain intact and not diminish in quality when arriving at the destination. The number of accidents occurs mostly caused by human error, such as the placement of people who are not in accordance with his exspertise, in- adequate 
ship maintenance, and unpredictable weather conditions. The problem often happens in the ship because of the pursuing to get high profits.

The problem is not only about the ship maintenance, in which the crew abandon on the ship but also because they are not worthy and competent in the field of the matter. This is the reason for the ship management to make it efficient. Related to the important role of the port and to anticipate the rate of development of sea transport flows in indonesia, the goverment has detemined the safety issue of the voyage to be a top priority. It has also been proclaimed in the "zero accidents" of marine transportation. Various efforts and cooperation of all components of sea transport should be made by the goverment as the regulator, the enterpreneur as the operator, and the community as the sevice user to fulfil the desire to arrive at the destination safely. The safety often turns into a catasthrophic crash that can eliminate the life of a good man and can cause very high material losses. ISM Code provides an international standard for the safety management of ship operations and for the prevention of accidents at the sea as an effort to enforce and improve the safety of shipping in Indonesian waters. The general director of sea transport has instructed the safety inspector officials of the vessel to be more throughly in inspecting and testing the feasibility of the vessels. It applies to the ship passengers and freight vessel as an effort to enforce and improve the safety of shipping in Indonesian water.

Careful supervision on examination and testing is done in accordance with the applicable provisions. When the inspection finds that the shipis not eligible, then it should be sanctioned by not issuing letters or documents related to the certification of that ship. This is done with the intgention of providing a deterrent effect to the owners of the ships or the companies that operate the vessel to always priorotize the safety factor in the voyage. The crew of the ship also must have competence through education in educational intitutions that have received goverment recognition. So, everyone working at a ship has a 
variety of competence certificates according to the ship where he works (Kania, n.d.). To be able to sail, the vessel must have various recognition of sea vessel from the goverment which is marked with the issuance of a ship's sea vessel setivicate.

The certificate of ship's sea life is also varied on the ship, for example ship board capability for vessel construction, hull, communications equipment, and also shipping safety equipment (Wiweko \& Edi, n.d.). The recognition is given in the form of certificates both for the competence of the crew as well as the condition of the vessel. The crew is considered to have the ability and skills in maintaining the operations. With the competence of the crew, they will always try to keep the ship in the sea to meet the safety of shipping. Cruise safety is the condition of the fullfillments of the requirements of ship's sea freight and navigability.(Cho, 2014). Sea worthy's boundary shall be filled with each vessel in accordance with its shipping area which includes the safety ofthe ship vessel, accident prevention, ship building, ship loading, welfare of the crew and passenger health. Beside that, the management of the ship also should care about the ship legal status, safety management, prevention of ship pollution and ship safety management. The fullfilment of any ship maritime requirements is evidenced by certificates and ship mail or letter.

The navigation consists of hydroghraphic and meteorological navigation, shipping navigation aids, grooves and crossings, dreeging and reclamation, pilotage on handling ship and salvage and underwater works (Lee \& Song, 2014). Based on the description above, there are two independent variables. They are safety management or $\mathrm{X} 1$ and supervision of marine inspector or $\mathrm{X} 2$. Both of them are suspected tohave a strong influence on the safety of the voyage (Y). The safety of the voyage is a condition of the fullfillment of safety and security requirements that concerning on water transport and ports with management indicators, crew, technical, procedures, regulations and prevention of ship wrecks or accidents. 


\section{Method}

The samples used in this study were be obtained by sampling tecnique of non capability sampling with sampling saturate. The researchers used this sampling technique because the population amount is 30 (Umagapi et al., 2016). The sample are the crew of MT. Marlin 8 ship at PT Patria nusasegara. In analyzing the data, the researchers used the correlation analysis with SPSS.(Simarmata \& Keke, 2017)

The hypotheses in this research are :

The first hypotesis :

Ho : $\rho 1=0$

There is no significant positive relation between safety management with MT. Marlin 8 safety sailing at PT Patria Nusasegara in 2017.

Ha $: \rho 1>0 \quad$ There is a significant positive relationship between the safety management of MT. Marlin 8 shipping at PT Patria Nusasegara in 2017.

The second hypothesis :

Ho $: \rho 2=0 \quad$ There is no significant positive relationship between the supervision of Marine Inspector and the safety of MT. Marlin 8 voyage at PT Patria nusasegara in 2017.

Ha $: \rho 2>0 \quad$ There is a significant positive relationship between the influence of marine inspector control and the safety of MT. Marlin 8 at PT Patria nusasegara in 2017.

The third Hyphotesist :

Ho : $\rho 1 \rho 2=0 \quad$ There is no significant positive relationship between Marin's safety management and marine inspector jointly with safety of the MT Voyage of MT Marlin 8 at PT Patria Nusasegara in 2017.

Ha: $\rho 1 \rho 2>0 \quad$ There is an equally significant positive correlation between safety management and marine inspector 
control with the safety of the voyages of MT. Marlin 8 at PT Patria Nusasegara in 2017.

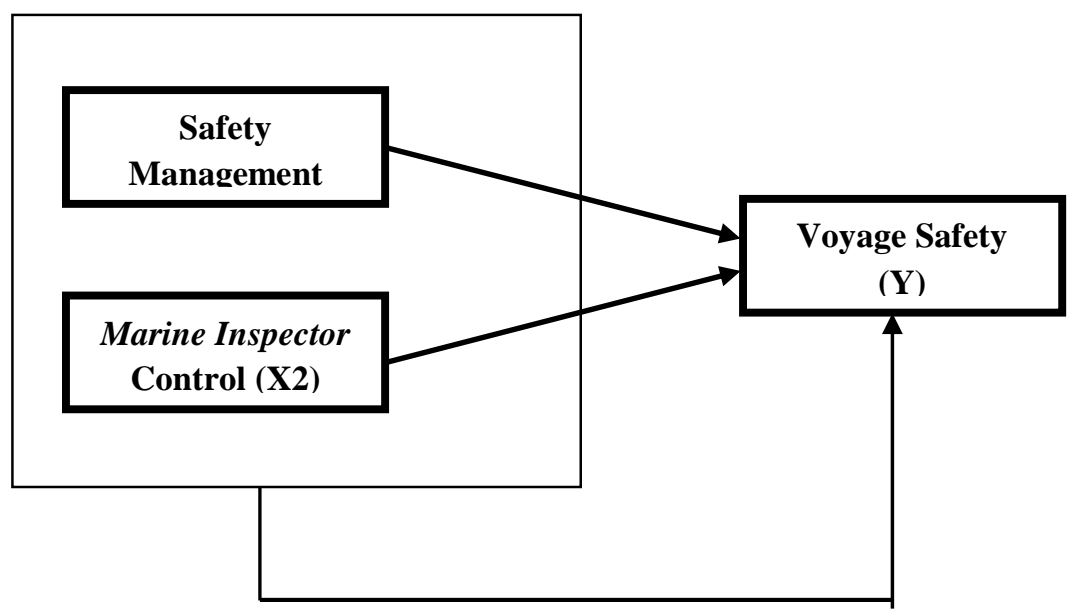

The type of the data that the researchesr used in this research is qualitative data with quantitative approach by means of giving questionnaires then numbering on safety management of marine inspector control and safety of voyage while the source data used is primary data source.

\section{Discussion and Result}

The result of safety management at PT Patria nusasegara is good because the average result of the responses of respondents show the average value of 134. Thus, the value of respondents' statements is in the category of strongly agree. The marine inspector control on PT Patria nusasegara is good because the average result of respondents' statement with an average value 130. Is in the category of strongly agree. Voyage safety of MT. Marlin 8 at PT Patria Nusasegara is good because the average result of the responses of respondents' show an average value of 131. Is in the category strongly agree. The safety management variables have a positive and significant relationship with the safety of MT. Marlin 8. Shipping, on the basis of the calculation results obtained, shows that the closeness of the relationship is indicated by correlation 
coefficient of 0,633 . It can be cocluded that the more tiered the more effective the safety of MT.Marlin 8.

Based on the calculation result, it is obtained that the closeness of the relationship is indicated by the correlation coefficient of 0,725 . It can be concluded that the high supervision of the marine inspector provides the higher safety of MT. Marlin 8. So, that's why the research hypothesis Ha2 is accepted because $\mathrm{T}_{\text {account }}>\mathrm{T}_{\text {table }}$ or 5,567>1,701, so Ho is refused and Ha is accepted. It means there is a significant positive relation between the supervision of marine inspector with the safety of voyage MT. Marlin 8.

The variable of safety management and supervision marine inspector together have positive and significant relation with safety of MT. Marlin 8 shipping on the basis of the calculation result. It is obtained that the closeness of the relationship is indicated by the correlation coefficient of magnitude 0,814 . It can be concluded that if the marine safety and supervision of the marine inspector are jointly enhanced, the voyage safety of MT Marlin 8 will increase. Thus the hypothesis of $\mathrm{H} 3$ research is accepted. Because $\mathrm{F}$ account> than $\mathrm{F}$ table or 26,427 > than 3,354 than Ho is rejected and Ha is accepted. It means, in the multiply ways we can see that there is a significant positive relation between safety management and marine inspector control with voyage safety MT. Marlin 8.

\section{Conclusion}

The company should maintain well executed procedures and maintenance planning mechanisms and keep in mind the idea from the captain and the beginning of another ship. The knowledge and the skills of the crew need to be improved through education or training organized by goverment/companies and training programs that held on board.(Tantri, n.d.). For the new ship operational pesonnels who want and just starts working on the tanker ship, they should understand and learn the functions of duties and responsibilites in working on 
the tanker vessel, especially the responsibility in the maintenance of tanker ship. It is necessary to commit the company to determine the planning of the use and the inventory of ship maintenance material. Therefore, it can be applied by the ship crew to be well managed.

\section{References}

Cho, H. S. (2014). Determinants and effects of logistics costs in container ports: The transaction cost economics perspective. Asian Journal of Shipping and Logistics, 30(2), 193-215. https://doi.org/10.1016/j.ajs1.2014.09.004

Lee, S. W., \& Song, J. M. (2014). Economic possibilities of shipping though Northern Sea Route. Asian Journal of Shipping and Logistics, 30(3), 415430. https://doi.org/10.1016/j.ajsl.2014.12.009

Simarmata, J., \& Keke, Y. (2017). The Influence of Travel Agent, Infrastructure and Accommodation on Tourist Satisfaction, 28(Ictgtd 2016), 281-283.

Tantri, F. (n.d.). The Inluence of Development Effectiveness and Education and Training Quality on The Driver' s Technical Skills of PT XYZ in Jakarta, 2(2), 169-176.

Umagapi, B. W., Manajemen, S. T., Trisakti, T., Amonalisa, S., Manajemen, S. T., Trisakti, T., ... Trisakti, T. (2016). Bongkar Muat General Cargo the Documents Service Quality and the Speed, 3(3), 379-386.

Wiweko, A., \& Edi, D. W. (n.d.). The Effect of Vessel Seaworthiness and Crew's Competence on Marine Safety, 2(3), 287-296. 